\title{
Microhabitat interactions of non-native pumpkinseed Lepomis gibbosus in a Mediterranean-type stream suggest no evidence for impact on endemic fishes
}

\author{
Nildeniz Top ${ }^{1 *}$, Ali Serhan Tarkan ${ }^{1}$, Lorenzo Vilizzi ${ }^{2}$ and Uğur Karakuş ${ }^{1}$ \\ ${ }^{1}$ Muğla Sitkı Koçman University, Faculty of Fisheries, 48000 Kötekli, Muğla, Turkey \\ ${ }^{2}$ Istanbul University, Faculty of Fisheries, 34470 Laleli, Istanbul, Turkey
}

\begin{abstract}
The pumpkinseed Lepomis gibbosus was introduced to Europe and parts of the Mediterranean Region more than 100 years ago. However, relatively little is known of its potential ecological impacts on the native species and freshwater ecosystems of Anatolia (Turkey), where the species is currently established in ponds and rivers. In this study, interactions between L. gibbosus and native and non-native stream fishes were investigated between June 2009 and May 2010 in Sarıçay Stream, a Mediterranean-type water course. Microhabitat preferences for depth, substratum composition, distance from bank and from vegetation, plant cover, velocity, turbidity and light intensity were studied by Constrained Quadratic Ordination. The species sampled in larger frequency of occurrence (and for which microhabitat relationships could be investigated) comprised endemic Smyrna chub Petroleuciscus smyrnaeus and Aegean chub Squalius fellowesii, and nonnative L. gibbosus (both juveniles and adults) and topmouth gudgeon Pseudorasbora parva. Adult L. gibbosus were found to prefer locations closer to the bank with less turbid water, plant cover, light intensity, woody structure and with sandy substratum whilst avoiding riffle habitats with coarser debris, deeper water, dense submersed aquatic vegetation and higher velocities. These preferences overlapped with those for the other nonnative species $P$. parva, but not with those for the endemic species and for $L$. gibbosus juveniles. The results of this study suggest that the potential for adverse impacts through competition for habitat of adult L. gibbosus with the native fish fauna is not apparent in Sarıçay Stream.
\end{abstract}

Keywords: endemic / invasion / lotic system / Constrained Quadratic Ordination (CQO)

\begin{abstract}
Résumé - Les interactions du microhabitat de la perche soleil Lepomis gibbosus dans une rivière de type méditerranéen ne suggèrent aucune preuve de l'impact sur les poissons endémiques. La perche soleil Lepomis gibbosus a été introduite en Europe et certaines parties de la région méditerranéenne, il y a plus de 100 ans. Cependant, on sait relativement peu sur ses impacts écologiques potentiels sur les espèces indigènes et les écosystèmes d'eau douce de l'Anatolie (Turquie), où l'espèce est actuellement implantée dans les étangs et les rivières. Dans cette étude, les interactions entre L. gibbosus et les poissons indigènes et non indigènes des cours d'eau ont été étudiées entre juin 2009 et mai 2010 dans la rivière Sariçay, un cours d'eau de type méditerranéen. Les préférences de microhabitat pour la profondeur, la composition du substrat, la distance de la rive et de la végétation, la ripisylve, la couverture végétale, la vitesse, la turbidité et les conditions de lumière ont été étudiées par ordination quadratique sous contraintes. Les espèces échantillonnées en plus grande abondance (et pour lesquelles les relations de microhabitat pouvaient être étudiées) étaient le chevesne Smyrna Petroleuciscus smyrnaeus et le chevesne Aegean Squalius fellowesii endémiques, et L. gibbosus non indigène (juvéniles et adultes) et le Pseudorasbora parva. Les adultes de L. gibbosus ont été trouvés préférer des endroits plus proches de la berge avec moins d'eau turbide, de la couverture végétale, de l'intensité lumineuse, de la structure ligneuse et du substrat de sable, tout en évitant des radiers avec des débris plus grossiers, plus profonds, à dense végétation aquatique submergée et des vitesses plus élevées. Ces préférences se chevauchent avec celles de l'autre des espèces non indigènes $P$. parva, mais pas avec celles des espèces endémiques et juvéniles de L. gibbosus. Les résultats de cette étude suggèrent que le risque d'effets indésirables par le biais de la concurrence pour l'habitat des adultes de L. gibbosus avec la faune de poissons indigènes ne sont pas évidents dans la rivière Sariçay.
\end{abstract}

Mots clés : endémisme / invasion / système lotique / ordination quadratique sous contraintes (CQO)

\footnotetext{
*Corresponding author : tnildeniz@gmail.com
} 


\section{Introduction}

Freshwaters are amongst the most impacted ecosystems in the world and are being continuously affected by increased rates of introduction of non-native fish (Marr et al., 2013). These introductions can occur either intentionally or accidentally, and are mainly the result of fisheries establishment, release of ornamental and bait fishes, or biomanipulation (Jackson and Grey, 2013; Tarkan et al., 2015). Although impacts of introduced non-native fish to the native fauna can occur in several ways, species-specific competition for habitat and food resources in the recipient environment is quite common (Cucherousset and Olden, 2011; Vilizzi et al., 2012; Paterson et al., 2015). For this reason, studies on habitat interactions of non-native species with native faunas can provide crucial insight into the long-term dynamics of species interactions within ecosystems (Lodge, 1993). Also, the invasion success of an introduced species in a new environment depends on its ability to adapt and use local resources (Fausch et al., 2001; Guo, 2006), and non-native fish species may cause a shift in local species community structure (Werner, 1984). Clearly, all of these aspects make the understanding of fish-habitat relationships a crucial requirement (Yamazaki et al., 2006).

An introduced species of particular interest is the North American pumpkinseed Lepomis gibbosus. Following its introduction to Europe in the late 1900s as an ornamental fish for estate ponds, it was first found in Turkish inland waters of the Thrace Region (European part of Turkey) in the early 1980s (Erk'akan, 1983; Baran and Ongan, 1988). In the 2000s, the species was introduced to Anatolia (Asian part of Turkey: Özcan, 2007; Ağdamar et al., 2015), and more recently the number of $L$. gibbosus populations in Turkish waters was reported to have increased (Tarkan et al., 2015). Whilst in southern Europe L. gibbosus has become a successful invader responsible for detrimental effects on the native fish fauna (Cucherousset et al., 2009), for Turkish inland waters it is still regarded as a 'potential' invader (Tarkan et al., 2015). This is because little information is available on its (putative) impacts on the native biota in a country characterised by a very rich endemic freshwater fish fauna $(\approx 322$ species in total, of which 215 or $66.8 \%$ endemic: Freyhof et al., 2014).

In general, pond-dwelling populations of L. gibbosus have been studied more frequently whereas studies of streamdwelling populations remain scarce. The latter studies have usually provided contrasting conclusions suggesting either potential ecological consequences or relatively harmless impacts (Godinho et al., 1997; Gutiérrez-Estrada et al., 2000; Villeneuve et al., 2005; Cucherousset et al., 2009; Almeida et al., 2014). However, despite the species' long-time presence in Europe and its fast spread across Anatolia, there have been only few studies on its habitat interactions in this area and virtually none in southern Europe (Gkenas et al., 2016).

Although early studies suggested that L. gibbosus displaced native Eurasian perch Perca fluvatilis in France (Roule, 1928, 1935), these were not quantitatively substantiated and later research has not provided support to this hypothesis (e.g. Copp, 1989a, 1993). The first detailed study on the habitat use of L. gibbosus and its interactions with native fish species was undertaken in a small river catchment of southern England (Klaar et al., 2004), where escapee L. gibbosus from floodplain ponds and reservoirs have become established. This and follow-up studies (Vilizzi et al., 2012; Stakènas et al., 2013) revealed strong habitat associations between L. gibbosus and native brown trout Salmo trutta, but suggested little or no impact (Gkenas et al., 2016). Although these reports are usually from lentic systems (Cucherousset et al., 2009), a recent study from a stream system in Spain revealed adverse aggressive impacts by L. gibbosus on non-native crayfish and especially endemic fishes and frogs (Almeida et al., 2014). However, except for circumstantial evidence on the displacement of native Iberian stream fish by L. gibbosus (Prenda et al., 2006; Ferreira et al., 2007), there has been no direct and detailed study on the habitat use and interactions of L. gibbosus with native or endemic species in the southern Mediterranean Region and particularly in Anatolia, where successful reproduction of L. gibbosus as a result of high water temperatures in streams is known to occur.

To fill this knowledge gap, the aim of the present study was to assess the habitat use of L. gibbosus in association with other fish species in a temperate stream characterised by a Mediterranean climate and high fish diversity with several non-native and endemic species. It was hypothesised that the high water temperatures and rich biodiversity of the stream would result in strong habitat interactions between $L$. gibbosus and the native species. The present findings will also contribute to identify the preferred habitat structure of L. gibbosus that allows for nest creation, which favours the species' successful reproduction and likely interactions with the recipient native fish (Copp et al., 2010).

\section{Materials and methods}

\subsection{Study area and sampling}

Sarıçay Stream flows into the Gulf of Güllük through the Muğla-Milas region in south-west Anatolia (Fig. 1). The stream is $\approx 80 \mathrm{~km}$ long, the average width of the river bed is $\approx 10 \mathrm{~m}$, and it hosts different habitat types (predominantly sand, gravel, mud and stone, and rock). Mean water temperatures change seasonally from an average of $25.2^{\circ} \mathrm{C}$ in summer, $20.2^{\circ} \mathrm{C}$ in autumn, $9.8^{\circ} \mathrm{C}$ in winter, and $13.3^{\circ} \mathrm{C}$ in spring. Two large reservoirs have been constructed along the stream's course and there are also small ponds formed by disused sandpits. The stream fish fauna includes both endemic (i.e. loach Oxynoemacheilus sp., Smyrna chub Petroleuciscus smyrnaeus, Aegean chub Squalius fellowesii) and non-native fish species (i.e. gibel carp Carassius gibelio, common carp Cyprinus carpio, eastern mosquitofish Gambusia holbrooki, topmouth gudgeon Pseudorasbora parva).

Sampling was conducted between June 2009 and May 2010, with samples collected at locations selected haphazardly by Point Abundance Sampling (PAS: Nelva et al., 1979) by Electrofishing (SAMUS-725MP, anode diameter of $2 \mathrm{~m}$ ). This method provides reproduceable and quantifiable samples and is efficient along the entire range of catchable fish sizes (Copp, 1989b). Sampling was carried out over a $\approx 300 \mathrm{~m}$ stream stretch $\left(37^{\circ} 20^{\prime} 35.2^{\prime \prime} \mathrm{N}, 27^{\circ} 43^{\prime} 38.0^{\prime \prime} \mathrm{E}\right)$ in summer (78 point 


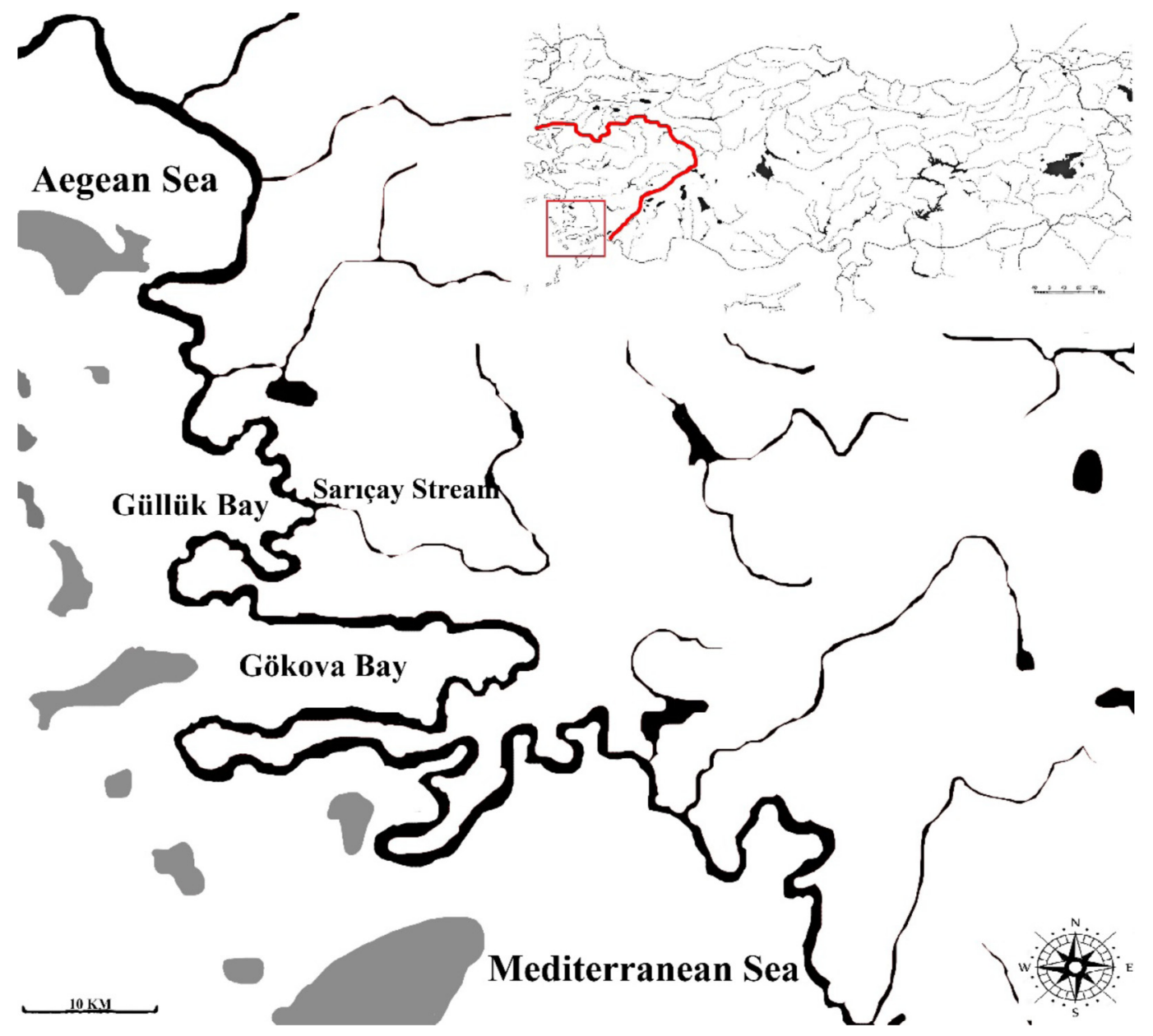

Fig. 1. Study area (Sarıçay Stream: south-west Anatolia, Turkey).

samples), winter (25), autumn (100) and spring (50), for a total of 253 random points. Maximum depth was $\approx 130 \mathrm{~cm}$ and electrofishing was effective even in the deeper parts of the river, where small and bottom-dwelling fish species were successfully captured. Juvenile L. gibbosus individuals were distinguished from adults based on a total length at maturity of $77.5 \mathrm{~mm}$ for the species in Sarıçay Stream (Top, 2012). Measurements of microhabitat variables included: (i) depth (cm), (ii) substratum composition (visually estimated as: mud, $<50 \mu \mathrm{m}$; silty sand, $>50 \mu \mathrm{m}$ to $0.06 \mathrm{~cm}$; sand, $>0.06-0.2 \mathrm{~cm}$; gravel, $>0.2-2.0 \mathrm{~cm}$; mud + stone, $>2.0-20.0 \mathrm{~cm}$; rock, $>20 \mathrm{~cm}$ as described in Beyer et al. (2007)), (iii) distance from bank (cm), (iv) distance from vegetation $(\mathrm{cm})$, (v) submersed aquatic vegetation, (vi) submersed woody structure (roots or other ligneous material), (vii) plant cover (all in \% of point area), (viii) water velocity (determined semi-quantitatively as described in Beyer et al. (2007), using a pole as: none, no ripple effect around the pole; medium fast: gentle ripple effect around the pole $\left(>0\right.$ but $\left.<5 \mathrm{~cm} \mathrm{~s}^{-1}\right)$; fast: elevated ripple effect around the pole $\left(5-10 \mathrm{~cm} \mathrm{~s}^{-1}\right)$, (ix) turbidity (estimated visually as: low, medium and high blurry), and (x) light intensity (at the water surface and categorised as: shady, sunny-shady, and sunny). Catch per Unit Effort (CPUE) was recorded simultaneously during electrofishing and expressed as number of fish specimens captured by cumulative time of electrofishing operations.

\subsection{Data analysis}

Constrained Quadratic Ordination (CQO) was used to analyse fish-habitat relationships (Yee, 2004). Compared to Canonical Correspondence Analysis (CCA), CQO overcomes the (unrealistic) assumptions of equal tolerances, equal maxima and uniformly distributed optima and site scores over the range of the environmental gradient (Yee, 2004), and has been recently applied successfully to the study of fish-habitat relationships (Vilizzi et al., 2012). Briefly, in CQO a sample $\times$ species data matrix is related to a sample $\times$ microhabitat variables data matrix, and the output is an ordination diagram. In the latter, the $x$-axis represents the 'latent variable' (sensu Bollen, 2002), which in the present study is a vector consisting of a linear combination of the microhabitat variables, whereas the $y$-axis plots the presence/ absence of the species on the latent variable axis. CQO estimates an optimal linear combination of the microhabitat variables (which are 'condensed' into the latent variable) and regresses the species' data upon the latent variable axis using a quadratic curve fitted across the species' scores. For the purposes of this study, each response curve (or profile) in the ordination diagram represents the distributional range of the species across the microhabitat gradient (i.e. the latent variable), so that the relative position of the curve along the gradient indicates the use/preference of the species for certain 


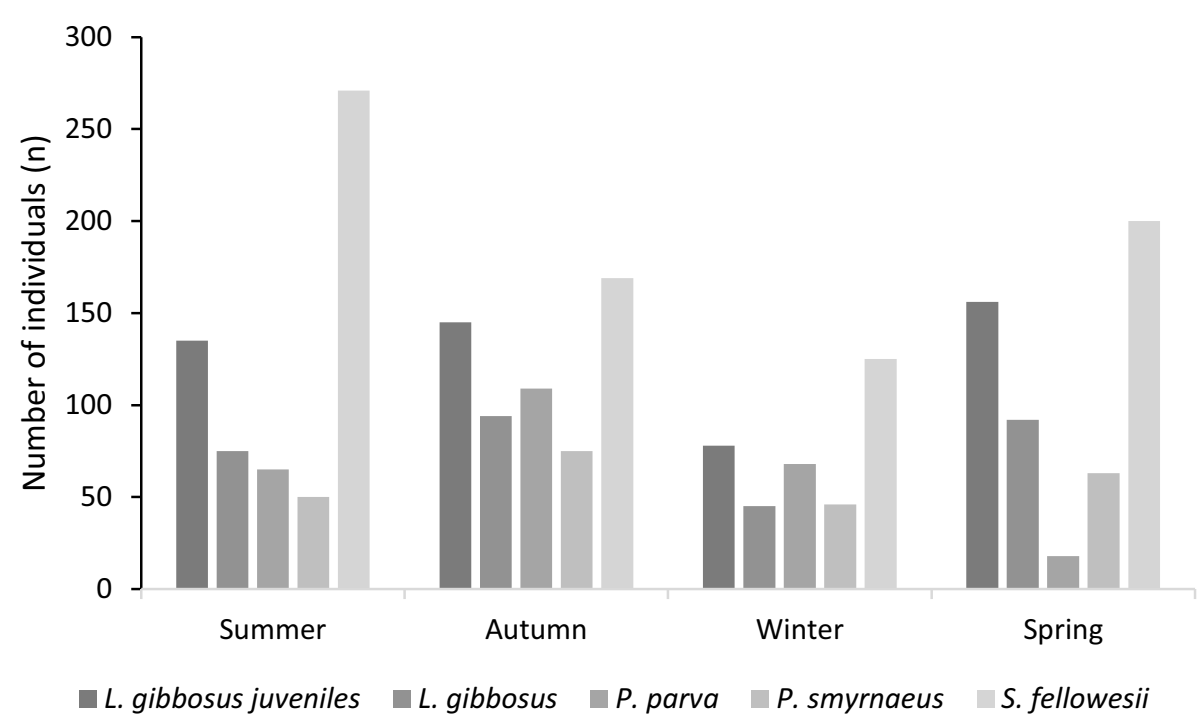

Fig. 2. Abundance of the most common fish species sampled from Sarıçay Stream according to season.

values of the microhabitat variables summarised into the microhabitat gradient, and as determined by the species' probability of occurrence. The optimum is the value along the microhabitat gradient at which the highest probability of occurrence for that species is recorded (Yee, 2004).

Using the entire set of 253 point samples, CQO models were fitted to presence/absence data for adult and juvenile L. gibbosus and $P$. parva as introduced species and for $S$. fellowesii and P. smyrnaeus as endemic species (note that because of the relatively large sample sizes required by the statistical procedure to ensure convergence, no season-wise analysis of the data was possible: see also Vilizzi et al., 2012). Depth, substratum composition, distance from bank, distance from vegetation, submersed aquatic vegetation, submersed woody structure, plant cover, velocity, turbidity and light intensity (defined as above) were the ten descriptors identifying the microhabitat latent variable. Fitting of CQO was under a binomial model of rank 1 , with three non-linear degrees of freedom and unequal tolerances and after choice of the 'best' 100 models (Yee, 2006). Implementation of models was in $\mathrm{R} \times 64$ v3.0.3 (R Development Core Team, 2015) using library VGAM v0.9-7 and following guidelines in Yee (2006).

\section{Results}

In total, 2341 fish in seven species were sampled. S. fellowesii $(n=765)$ and juvenile (306) and adult L. gibbosus (514) were the most abundant, followed by P. smyrnaeus (234) and P. smyrnaeus (234). Gambusia holbrooki (232), albeit abundant, was found only in a few locations and mostly as $0+$ juveniles, and was therefore removed from the dataset for CQO analysis. Similarly, C. gibelio (6), C. carpio (3) and Oxynoemacheilus sp. (21) occurred too infrequently in samples to permit microhabitat analysis.

The relative abundances of the five fish species retained for the study of fish-microhabitat relationships indicated seasonal variability. Thus, $S$. fellowesii was the most abundant species in all seasons, followed by juvenile L. gibbosus. P. parva was the least abundant species in spring but relatively more abundant in autumn. Finally, adult L. gibbosus were the least abundant species only in winter, whereas this was true of P. smyrnaeus in all seasons except spring (Fig. 2).

Based on CQO, turbidity ( -0.941$)$, substratum composition $(-0.422)$, light intensity $(-0.345)$, distance from bank $(-0.295)$, submersed woody structure $(-0.182)$ and plant cover $(-0.174)$, in that order, were the descriptors with negative loadings on the microhabitat latent variable axis; whereas, depth (0.339), submersed aquatic vegetation (0.336), distance from vegetation (0.297) and velocity (0.122) had positive loadings (Fig. 3). Turbidity was the major microhabitat driver with by far the largest loading. Unimodal, bellshaped curves were fitted to $P$. parva (optimum $=-6.264$; tolerance $=1.47)$ and L. gibbosus $(-4.804 ; 1$, as reference value), which showed a preference for less turbid waters, whereas the opposite was true for P. smyrnaeus $(-5.406 ; 2.99)$, which also preferred higher depths. The lack of any optima for S. fellowesii and L. gibbosus juveniles and the presence of an 'inverse' bell-shaped curve within the negative range of values of the latent variable indicated avoidance of the microhabitats preferred by P. parva and adult L. gibbosus (Fig. 3). Overall, adult L. gibbosus in Sarıçay Stream preferred locations closer to the bank with less turbid water, plant cover, light intensity and woody structure and with sandy substratum whilst avoiding riffle habitats with coarser debris, deeper water, dense submersed aquatic vegetation and higher velocities. Except for the other non-native P. parva, these preferences were not shared by either the endemic species or juvenile L. gibbosus, with the latter demonstrating a partial habitat overlap with one of the two endemic species under study (i.e. S. fellowesii).

\section{Discussion}

L. gibbosus have been reported to prefer generally sandy and slow-flowing river branches and oxbows, and to inhabit mainly still waters, reservoirs, floodplain lakes, ponds and 
N. Top et al. : Knowl. Manag. Aquat. Ecosyst. 2016, 417,

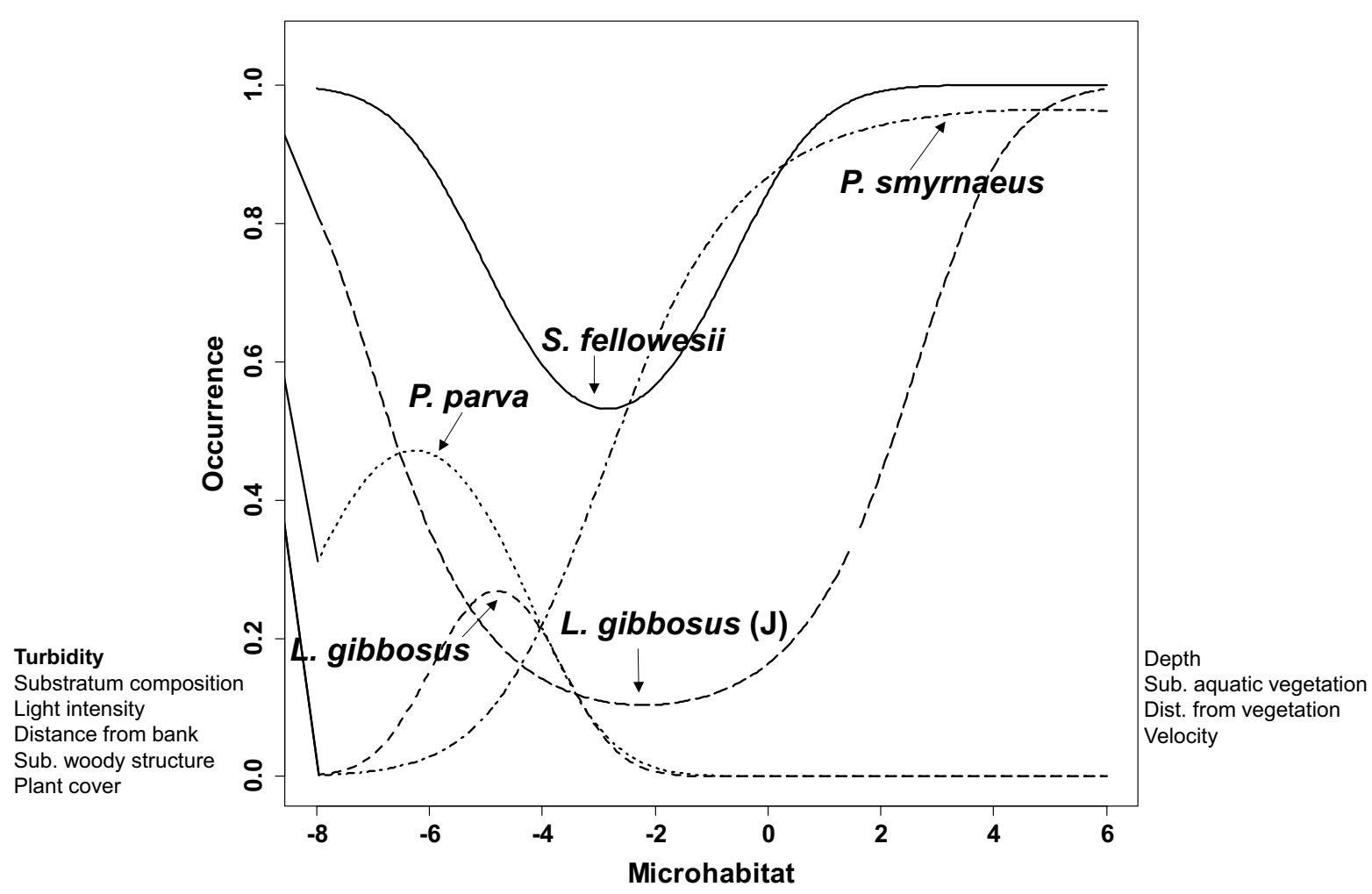

Fig. 3. Constrained Quadratic Ordination (CQO) plots for the most abundant fish species sampled from Sarıçay Stream. A summary indication of the main microhabitat features is provided on the negative and positive boundaries of the microhabitat (latent) variable axis.

marshes with avoidance of deeper areas (e.g. Balon, 1959; Crivelli and Mestre 1988; Copp et al., 2002). Although these habitat preferences were overall in accordance with the findings of the present study, the lack of a habitat overlap with the native species disagrees with previous studies on habitat association with native brown trout in a small river in England, where water temperatures may not reach the necessary levels for the species' optimal reproduction (Vilizzi et al., 2012; Stakènas et al., 2013). In this regard, all previous studies conducted in England have shown that L. gibbosus occur randomly in river systems of the region and are generally found as small individuals $(<40 \mathrm{~cm}$ TL) escaped from closed still water sources (e.g. ponds, lakes, reservoirs: Copp and Fox, 2007). However, the present results also do not corroborate the findings from Almeida et al. (2014) of negative impacts, hence do not support the hypothesis of increased habitat affinity with native and endemic species under elevated water temperatures (suitable for successful reproduction and establishment of L. gibbosus).

The observed similarity in habitat preferences between adult $L$. gibbosus and $P$. parva and dissimilarity with the native species can be interpreted in two ways. Firstly, these two nonnative species could have replaced local species in the stream, even though this contention would be hard to support in the absence of pre-introduction or isotope-based analysis studies able to unravel trophic changes over time (e.g. Jackson et al., 2016). Secondly, the two non-native species may be using different trophic levels to avoid habitat overlap with the resident native species. In this regard, a recent study suggested that $P$. parva invasion resulted in niche differentiation, with the species being found at a lower trophic position relative to some native species (Tran et al., 2015). Declerck et al. (2002) found a moderate overlap between $P$. parva and L. gibbosus, which can shift their niche for different food sizes. However, niche overlap can be difficult to interpret because species may modify their niche according to competition for resources. Werner (1984) suggested that an introduced species able to utilise resources efficiently may lead to an expansion in the native species' diet. Both of the non-native species examined in the present study prefer habitats with increased complexity with plant cover and woody structure (e.g. branches, roots), and this habitat complexity could provide variable feeding opportunities by spatial segregation for both species (Declerck et al., 2002) as well as shelter for competitors (Fisher Huckins et al., 1999). Also, rich food and nutrient availability in Sarıçay Stream (Top, 2012) may lead to reduce competition. Indeed, results of Karakuş (2014), who investigated feeding interactions of the fish species in Sarıçay Stream, support this contention, with $P$. parva showing limited interactions with the native species but a significant one with L. gibbosus. On the contrary, in a turbid shallow lake of Central Europe, L. gibbosus and P. parva were reported to occur in large numbers within reeds, but no significant overlap for diet was found (Wolfram-Wais et al., 1999).

Although no significant habitat overlap was detected between adult $L$. gibbosus and the endemic species of Sarıçay Stream, a constant decline in the abundance of $P$. smyrnaeus was still observed (Fig. 2). This was regardless of the large microhabitat loading of P. smyrnaeus, which does not imply that the species was abundantly captured, as only presence/ absence relationships were investigated in the present study. Thus, the decline in abundance was likely due to the low 
N. Top et al. : Knowl. Manag. Aquat. Ecosyst. 2016, 417,

environmental tolerance of the species as a result of worsening habitat conditions (Özdemir et al., 2015). However, given the overall pronounced niche differentiation observed in the present study, non-native L. gibbosus and P. parva at this stage may be considered not to pose a threat to the endemic species of Sarıçay Stream. Indeed, endemic S. fellowesii was found in high abundance, similar to other streams and lakes of the Aegean region (Özdemir et al., 2015; Top et al., 2016).

Overall, the present results support recent findings on feeding interactions between native and non-native fishes (Karakuş, 2014; Jackson et al., 2016) and suggest that the potential for adult L. gibbosus to cause adverse impacts through habitat competition with the native species is not apparent in Sarıçay Stream. This is at variance with other studies carried out using different methodologies (e.g. snorkelling) and investigating different effects (e.g. aggression) under similar climate and environmental conditions (e.g. Almeida et al., 2014). Notably, the present outcome would invalidate prediction that climate change could favour $L$. gibbosus reproduction and subsequent establishment and impact on the native fauna (as is the case for the UK: Copp et al., 2010), and this is especially true should habitat complexity and food resources be high enough. In this regard, the tenet that invasive species differ from non-native species by exerting impacts on the recipient ecosystem was not supported for L. gibbosus and P. parva in Sarıçay Stream. However, support to this conclusion may be eventually provided through e.g. food-web analyses (Cucherousset and Olden, 2011; Tran et al., 2015; Jackson et al., 2016) and/or by more studies on habitat associations from different stream systems, especially Mediterranean-type ones in southern Europe. Finally, the results of the present study could have benefited from the sampling of 'control' sites where $L$. gibbosus does not occur. Pending further investigations, the present results should be regarded as preliminary.

As was the case with the present study, the importance of reporting on instances where non-native fishes exert negligible (or no) impacts on the native biota should be emphasised, as most of the literature tends to prioritise the existence of negative effects (e.g. Gozlan, 2008). Indeed, this practice would provide for a more comprehensive approach to the understanding of the ecology of non-native fishes introductions and related management (Britton et al., 2011).

\section{Conflict of interest}

The authors declare that they have no conflict of interest.

Acknowledgments. This study was supported by the Research Fund of Muğla Sitkı Koçman University (Project No: 09/28). We thank the General Directorate of Protection and Control, Ministry of Agriculture and Rural Affairs, Republic of Turkey for providing permission to carry out sampling for the present study.

\section{References}

Ağgdamar S, Tarkan AS, Keskin E, Top N, Doğaç E, Baysal Ö. 2015. The role of environmental factors and genetic diversity on colonization success of a non-native fish, Lepomis gibbosus from western part of Turkey. Biochem Syst Ecol 58: 195-203.

Almeida D, Merino-Aguirre R, Vilizzi L, Copp GH. 2014. Interspecific aggressive behaviour of invasive pumpkinseed Lepomis gibbosus in Iberian fresh waters. PLoS ONE 9(2): e88038, Doi:10.1371/journal.pone.008803.

Balon EK. 1959. Spawning of Lepomis gibbosus (L.) acclimatised in the back water of the Danube and its development during the embryonic period. Věst Česk Spol Zool 23: 1-22 (in Slovak with English summary).

Baran I, Ongan T. 1988. Gala Gölü'nün limnolojik özellikleri. Balıkçılık Sorunları ve Öneriler. Gala Gölü ve Sorunları Sempozyumu, Doğal Hayatı Koruma Derneği Bilimsel Yayınlar Serisi, Istanbul 46-54 (in Turkish with English summary).

Beyer K, Copp GH, Gozlan RE. 2007. Microhabitat use and interspecific associations of introduced topmouth gudgeon Pseudorasbora parva and native fishes in a small stream. $J$ Fish Biol 71: 224-238.

Bollen KA. 2002. Latent variables in psychology and the social sciences. Annu Rev Psychol 53: 605-634.

Britton JR, Gozlan RE, Copp GH. 2011. Managing non-native fish in the environment. Fish Fish 12: 256-274.

Copp GH. 1989a. The habitat diversity and fish reproductive function of floodplain ecosystems. Environ Biol Fishes 26: 1-26.

Copp GH. 1989b. Electrofishing for fish larvae and juveniles: equipment modifications for increased efficiency with short fishes. Aquacult Fish Manag 20: 453-462.

Copp GH. 1993. The upper River Rhone revisited: an empirical model of microhabitat use by 0+ juvenile fishes. Folia Zool 42: 329-340.

Copp GH, Fox MG. 2007. Growth and life history traits of introduced pumpkinseed (Lepomis gibbosus) in Europe, and the relevance to invasiveness potential. In: Gherardi F, ed. Freshwater Bioinvaders: Profiles, Distribution, and Threats. Berlin: Springer, pp. 289-306.

Copp GH, Fox MG, Kováč V. 2002. Growth, morphology and life history traits of a coolwater European population of pumpkinseed Lepomis gibbosus. Arch Hydrobiol 155: 585-614.

Copp GH, Stakenas S, Cucherousset J. 2010. Aliens versus the natives: interactions between introduced Lepomis gibbosus and indigenous Salmo trutta in small streams of southern England. Am Fish Soc 73: 347-370.

Crivelli AJ, Mestre D. 1988. Life history traits of pumpkinseed Lepomis gibbosus introduced into the Camargue, a Mediterranean wetland. Arch Hydrobiol 111: 449-466.

Cucherousset J, Olden JD. 2011. Ecological impacts of nonnative freshwater fishes. Fisheries 36: 215-230.

Cucherousset J, Copp GH, Fox MG, et al. 2009. Growth, life-history traits and potential invasiveness of introduced pumpkinseed Lepomis gibbosus populations in Northern Europe. Biol Invasions 11: 2171-2180.

Declerck S, Louette G, De Bie T, De Meester L. 2002. Patterns of diet overlap between populations of non-indigenous and native fishes in shallow ponds. J Fish Biol 61: 1182-1197.

Erk'akan F. 1983. The fishes of the Thrace Region. Hacettepe Bull Nat Sci Eng 12: 39-48.

Fausch KD, Taniguchi Y, Nakano S, Grossman GD, Townsend CR. 2001. Flood disturbance regimes influence rainbow trout invasion success among five Holarctic regions. Ecol Appl 11: 1438-1455.

Ferreira MT, Oliveira J, Caiola N, et al. 2007. Ecological traits of fish assemblages from Mediterranean Europe and their responses to human disturbance. Fish Manag Ecol 14: 473-481.

Fisher Huckins CJ, Osenberg CW, Mittelbach GG. 1999. Species introduction and their ecological consequences: an example with congeneric sunfish. Ecol Appl 10: 612-625. 
N. Top et al. : Knowl. Manag. Aquat. Ecosyst. 2016, 417,

Freyhof J, Ekmekçi FG, Ali A, et al. 2014. Freshwater fishes. In: Smith KG, Barrios V, Darwall WRT, Numa C, eds. The Status and Distribution of Freshwater Biodiversity in the Eastern Mediterranean. Cambridge, UK, Malaga, Spain and Gland, Switzerland: IUCN. $\mathrm{xiv}+132 \mathrm{p}$.

Gkenas C, Magalhães MF, Cucherousset J, Domingos I, Ribeiro F. 2016. Long term patterns in the late summer trophic niche of the invasive pumpkinseed sunfish Lepomis gibbosus. Knowl Manag Aquat Ecosyst 417: 19.

Godinho FN, Ferreira MT, Cortes RV. 1997. The environmental basis of diet variation in pumpkinseed sunfish, Lepomis gibbosus, and largemouth bass, Micropterus salmoides, along an Iberian river basin. Environ Biol Fish 50: 105-115.

Gozlan RE. 2008. Introduction of non-native freshwater fish: is it all bad? Fish Fish 9: 106-115.

Guo Q. 2006. Intercontinental biotic invasions: what can we learn from native populations and habitats? Biol Invasions 8: 1451-1459.

Gutiérrez-Estrada JC, Pulido-Calvo I, Fernádez-Delgado CG. 2000. Age-structure, growth and reproduction of the introduced pumpkinseed (Lepomis gibbosus, L 1758) in a tribuary of the Guadalquivir River (Southern Spain). Limnetica 19: 21-29.

Jackson MC, Grey J. 2013. Accelerating rates of freshwater invasions in the catchment of the River Thames. Biol Invasions 15: 945-951.

Jackson MC, Britton JR, Cucherousset J, et al. 2016. Do non-native pumpkinseed Lepomis gibbosus affect the growth, diet and trophic niche breadth of native brown trout Salmo trutta? Hydrobiologia 772: 63-75.

Karakuş U. 2014. Dietary interactions between non-native species Pseudorasbora parva (Temminck \& Schlegel, 1846) and some other fish species in Sarıçay Stream-Muğla. MSc Dissertation. Muğla Sıtkı Koçman University. Muğla, Turkey, 72 p. (in Turkish with English summary).

Klaar M, Copp GH, Horsfield R. 2004. Autumnal habitat use of nonnative pumpkinseed Lepomis gibbosus and associations with native fish species in small English streams. Folia Zool 53: 189-202.

Lodge DM. 1993. Biological invasions: lessons for ecology. Trends Ecol Evol 8: 133-137.

Marr SM, Olden JD, Leprieur F, et al. 2013. A global assessment of freshwater fish introductions in mediterranean-climate regions. Hydrobiologia 719: 317-329.

Nelva A, Persat H, Chessel D. 1979. Une nouvelle méthode d'étude des peuplements ichtyologiques dans les grands cours d'aeu par échantillonnage ponctuel d'abodance. C R Acad Sci III Paris 289: $1295-1298$

Özcan G. 2007. Distribution of the non-native fish species, pumpkinseed Lepomis gibbosus (Linnaeus, 1758), in Turkey. Aquat Invasions 2: 146-148.

Özdemir N, Tarkan AS, Ağdamar S, Top N, Karakuş U. 2015. Ecological requirements and distribution of native and introduced freshwater fishes in a Mediterranean-type basin (Muğla, SW Turkey). Fresen Environ Bull 24: 3-13.

Paterson RA, Dick JT, Pritchard DW, Ennis M, Hatcher MJ, Dunn AM. 2015. Predicting invasive species impacts: a community module functional response approach reveals context dependencies. J Anim Ecol 84: 453-463.
Prenda J, Clavero M, Blanco-Garrido F, Menor A, Hermoso V. 2006. Threats to the conservation of biotic integrity in Iberian fluvial ecosystems. Limnetica 25: 377-388.

Roule L. 1928. Les poissons et le monde vivant deseaux. In: Tome II. La vie et l'action, Paris: Librairie Delagrave, 235 p.

Roule L. 1935. Les poissons et le monde vivant deseaux. In: Tome VIII. Les poissons des eaux douces, Paris: Librairie Delagrave, pp. $47-172$.

Stakenas S, Vilizzi L, Copp GH. 2013. Habitat use, home range, movements and interactions of introduced Lepomis gibbosus and native Salmo trutta in a small stream of Southern England. Ecol Freshw Fish 22: 202-215.

Tarkan AS, Marr SM, Ekmekçi FG. 2015. Non-native and translocated freshwater fish species in Turkey. Fishmed 2015.003: 1-28.

Top N. 2012. Bio-ecological features of exotic Lepomis gibbosus (Linneaeus, 1758) (pumpkinseed) in Sarıçay stream. MSc Dissertation. Muğla Sitkı Koçman University. Muğla, Turkey, 69 p. (in Turkish with English summary).

Top N, Tarkan AS, Akbas F, Karakus U. 2016. Growth and life history traits of Aegean chub, Squalius fellowesii (Gunther, 1868) in streams in Mugla Province, Aegean coast, Turkey. J Appl Ichthyol 32: 532-537.

Tran TNQ, Jackson MC, Sheath D, Verreycken H, Britton JR. 2015. Patterns of trophic niche divergence between invasive and native fishes in wild communities are predictable from mesocosm studies. J Anim Ecol 84: 1071-1080.

Vilizzi L, Stakenas S, Copp GH. 2012. Use of constrained additive and quadratic ordination in fish habitat studies: an application to introduced pumpkinseed (Lepomis gibbosus) and native brown trout (Salmo trutta) in an English stream. Fundam Appl Limnol 180: 69-75.

Villeneuve F, Copp GH, Fox MG, Stakènas S. 2005. Interpopulation variation in the growth and life history traits of the introduced sunfish, pumpkinseed Lepomis gibbosus, in Southern England. J Appl Ichthyol 21: 275-281.

Werner EE. 1984. The mechanisms of species interactions and community organization in fish. In: Strong DR, Simberloff D, Abele LG, Thistle AB, eds. Ecological Communities: Conceptual Issues and the Evidence. Princeton, NJ: Princeton University Press, pp. 360-382.

Wolfram-Wais A, Wolfram G, Auer B, Mikschi E, Hain A. 1999. Feeding habits of two introduced fish species (Lepomis gibbosus, Pseudorasbora parva) in Neusiedler See (Austria), with special reference to chironomid larvae (Diptera: Chironomidae). Hydrobiologia 408/409: 123-129.

Yamazaki Y, Haramoto S, Takeshi F. 2006. Habitat uses of freshwater fishes on the scale of reach system provided in small streams. Environ Biol Fish 75: 333-341.

Yee TW. 2004. A new technique for maximum-likelihood canonical Gaussian ordination. Ecol Monogr 74: 685-701.

Yee TW. 2006. VGAM Family Functions for ReducedRank Regression and Constrained Ordination. Beta version 0.6-5. http://www.stat.auckland.ac.nz/ yee/VGAM/doc/rrvglm. pdf

Cite this article as: Top N, Tarkan AS, Vilizzi L, Karakuş U. 2016. Microhabitat interactions of non-native pumpkinseed Lepomis gibbosus in a Mediterranean-type stream suggest no evidence for impact on endemic fishes. Knowl. Manag. Aquat. Ecosyst., 417, 36. 